\title{
Efficient Nanoparticle-Templated Assembly of Viral Protein Cages
}

\author{
Supporting Information
}

\section{A) Synthesis of $16 \mathrm{~nm}$ citrate-GNPs:}

The $16 \mathrm{~nm}$ citrate-GNPs were obtained using the Frens' protocol [1] by heating $50 \mathrm{ml}$ of an aqueous solution of $\mathrm{HAuCl}_{4}\left(10^{-2} \%\right)$ to boiling, adding $1 \mathrm{~mL}$ of aqueous trisodium citrate solution (1\%) to the boiling solution., and then boiling the resulting mixture during $30 \mathrm{~min}$. During the reaction, the solution should first turn faintly blue in color when nucleation occurred, followed by a sudden colour change to red when the monodisperse solution particles is formed. The UV-Vis spectrum exhibits a characteristic plasmon band at 520 $\mathrm{nm}$. The diameter of the particles, measured from TEM images, was $16.3 \mathrm{~nm}+/-1.3 \mathrm{~nm}$. These colloidal gold particles have been used as starting products for the preparation of PEG-gold nanoparticles.

\section{B) Synthesis of PEG-GNPs:}

In the following, we describe the procedure used to prepare the PEG-coated gold nanoparticles (PEG-GNPs) starting from citrate-stabilized particles (scheme 1):

$\mathrm{HAuCl}_{4}+$ citrate $\underset{\mathrm{H}_{2} \mathrm{O}}{\stackrel{\text { tannic acid }}{\longrightarrow}}$

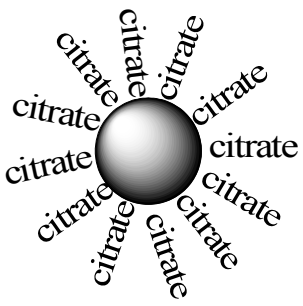

citrate GNP<smiles>O=C(O)OS</smiles><smiles>C1CCOCC1</smiles>

1

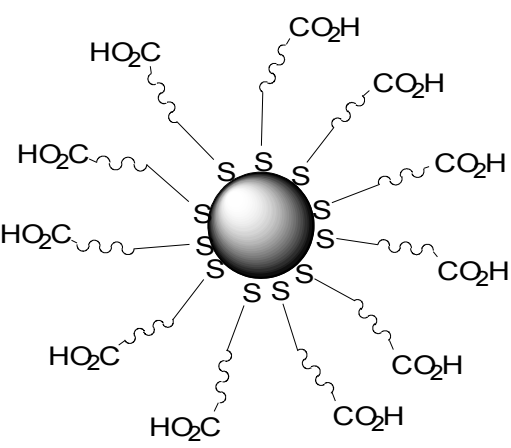

PEG-GNP

\section{$\underline{\text { Scheme } 1}$}

\section{Synthesis of citrate GNPs:}

The protocol designed by Slot and Geuze [2] has been adopted to make uniform-sized gold nanoparticles: (1) $1 \mathrm{~mL}$ of $1 \%(\mathrm{w} / \mathrm{v})$ tetrachloroauric acid $\left(\mathrm{HAuCl}_{4}\right)$ was added to $79 \mathrm{~mL}$ of water to make solution A. (2) A mixture consisting of $4 \mathrm{~mL}$ of $1 \%(\mathrm{w} / \mathrm{v})$ trisodium citrate 
dehydrate, $80 \mu \mathrm{L}$ of $1 \%$ tannic acid and $80 \mu \mathrm{L}$ of $25 \mathrm{mM} \mathrm{K}_{2} \mathrm{CO}_{3}$ and distilled water to reach 20 $\mathrm{mL}$ made solution B. (3) Both solutions were heated to $60^{\circ} \mathrm{C}$. (4) Solution B was rapidly added with stirring to solution A. (5) The reaction mixture was brought to boiling for 5 minutes. During (4) and (5), the mixture underwent a color change from blue to purple to a final color of red. (6) The mixture was cooled down to room temperature.

The plasmon band of these gold particles was observed at $519 \mathrm{~nm}$. Their size, measured from TEM images, was $11.2 \mathrm{~nm}+/-0.9 \mathrm{~nm}$.

\section{Synthesis of PEG-GNPs:}

The PEG-GNPs were obtained from the citrate GNPs by exchange of citrate molecules with the thiol ligand $\mathbf{1}$. This reaction was performed according the literature [3]. A large excess equivalent of thiol ligand was used: 100 monolayers/ particle, estimated by assuming that the occupied surface area by a single thiol molecule is ca. $0.20 \mathrm{~nm}^{2}$ [4]. Using this calculation, 10 $\mathrm{mg}$ of ligand 1 was added into the citrate GNPs solution. The mixture was rapidly stirred at room temperature for $20 \mathrm{~h}$ during which the color of the solution became slightly darker. Then, 3 volumes of THF were added to the reaction mixture and the resulted solution was centrifuged at $25,000 \mathrm{~g}$. at $4^{\circ} \mathrm{C}$ during $30 \mathrm{~min}$. The supernatant was removed, the pellet was re-dissolved into $10 \mathrm{~mL}$ of ultra pure water $(18 \mathrm{M} \Omega . \mathrm{cm}), 30 \mathrm{~mL}$ of THF was added and a second centrifugation in same conditions was carried out. The pellet was then dissolved into ultra pure water $(18 \mathrm{M} \Omega . \mathrm{cm})$ and kept at room temperature.

The plasmon band of these particles was observed at $524 \mathrm{~nm}$. The size of the gold core particles measured from TEM images was $11.1 \mathrm{~nm}+/-0.9 \mathrm{~nm}$. The size of the global gold particle (core + PEG layer), measured from stained TEM images, was $15.5 \mathrm{~nm}+/-1.5 \mathrm{~nm}$.

\section{C) Incorporation of gold particles into BMV capsids:}

$10 \mu \mathrm{L}$ of purified BMV proteins were diluted to a concentration of $0.3 \mathrm{mg} / \mathrm{mL}$ using TKM buffer (10 mM Tris-HCl; $1 \mathrm{M} \mathrm{KCl} ; 5 \mathrm{mM} \mathrm{MgCl}$; $\mathrm{pH} 7.4$ ).

1 equiv. of gold particles per expected virus was measured, evaporated and redissolved into $50 \mu \mathrm{L}$ of TKM buffer.

BMV proteins and gold particles were mixed into a dialysis bag and dialysed at $4{ }^{\circ} \mathrm{C}$ for ca. 20 h. against $100 \mathrm{~mL}$ of assembly buffer $(50 \mathrm{mM}$ Tris- $\mathrm{HCl} ; 50 \mathrm{mM} \mathrm{NaCl} ; 10 \mathrm{mM} \mathrm{KCl} ; 5$ $\mathrm{mM} \mathrm{MgCl} ; 2 ; \mathrm{pH} 7.4)$.

Then, the mixture was dialysed against $100 \mathrm{~mL}$ of SAMA buffer $(50 \mathrm{mM} \mathrm{NaOAc} ; 8$ $\mathrm{mM} \mathrm{Mg}(\mathrm{OAc})_{2} ; \mathrm{pH} 4.5$, adjusted by acetic acid) to reach $\mathrm{pH} 4.5$.

The sample was kept at $4^{\circ} \mathrm{C}$.

Sizes of the virus-like particles obtained from $1 \% \mathrm{U}(\mathrm{Ac})_{2}$ stained TEM images:

- With citrate-GNPs: $26.6+/-2.1 \mathrm{~nm}$.

- With PEG-GNPs: $25.6+/-1.2 \mathrm{~nm}$

The DLS (dynamic light scattering) graph of PEG-GNPs virus-like particles shows that the sample was monodispersed (the polydispersity is below 0.1). The mean diameter is 30.18 nm: 


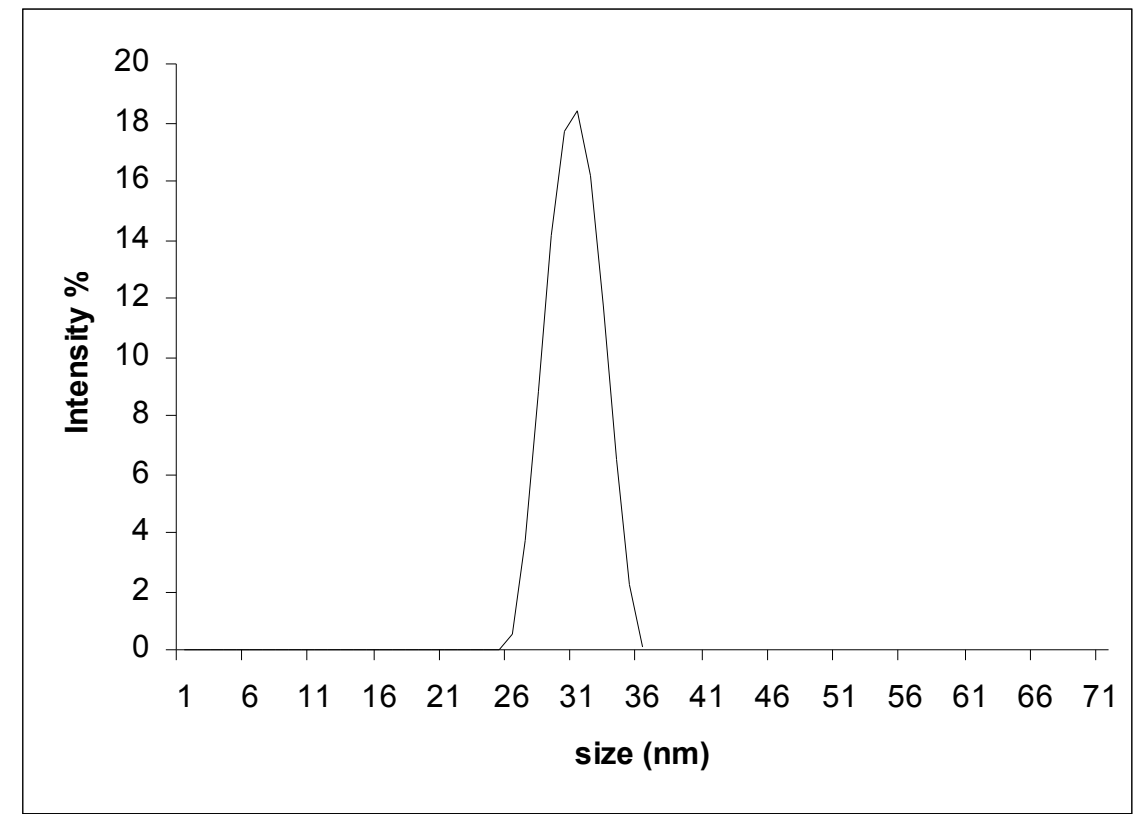

Figure 1. Typical dynamic light scattering result from PEG-GNP virus-like particles.

\section{D) Assembly reaction with BMV protein alone:}

The same reassembly reaction was carried out with BMV protein alone to compare with the capsid growth in the presence of PEG-GNPs. The transmission electron micrograph of an 1\% uranyl acetate stained sample of capsids formed using the protocol in $(\mathbf{C})$, which shows many more incomplete capsids than the reaction with PEG-GNPs, Figure 2. This indicates that PEGGNP cores greatly facilitated efficient capsid assembly.

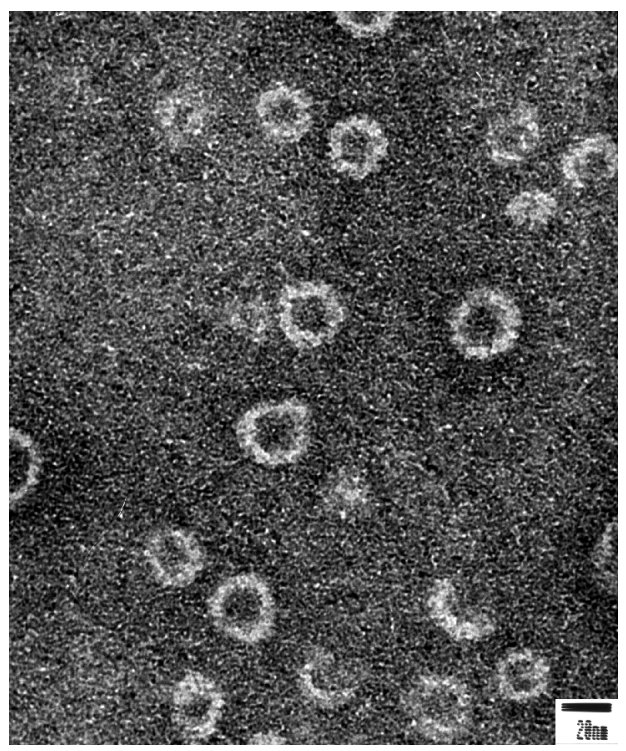

Figure 2. Control experiment with empty capsids forming through the same protocol as for gold nanoparticle incorporation.

(1) Frens, G. Nature-Physical Science 1973, 241, 20-22. 
(2) Slot, J. W.; Geuze, H. J. European Journal of Cell Biology 1985, 38, 87-93.

(3) Zhu, T.; Vasilev, K.; Kreiter, M.; Mittler, S.; Knoll, W. Langmuir 2003, 19, 9518-9525.

(4) Kimura, K.; Takashima, S.; Ohshima, H. Journal of Physical Chemistry B 2002, $106,7260-7266$. 